http://jmscr.igmpublication.org/home/ ISSN (e)-2347-176x ISSN (p) 2455-0450

crossref DOI: https://dx.doi.org/10.18535/jmscr/v8i3.26

\title{
The Management and Outcome of Peripheral Ulcerative Keratitis (PUK) in Bangladesh
}

\author{
Dr Farhat Jahan ${ }^{1 *}$, Dr Mehbub Ul Kadir ${ }^{2}$, Dr Chandana Sultana ${ }^{3}$, Dr Md. Saifulla \\ ${ }^{1}$ Asst. Professor, National Institute of Ophthalmology \& Hospital, Dhaka, Bangladesh \\ ${ }^{2}$ Junior Consultant, Sk. Fazilatunnesa Mujib Eye Hospital, Gopalgonj, Bangladesh \\ ${ }^{3}$ Asst.Professor \& Head of Dept. Cornea Clinic, Ispahani Islamia Eye Institute \&Hospital, Dhaka, \\ Bangladesh \\ ${ }^{4}$ Professor, Cornea Department, National Institute of ophthalmology \& Hospital, Dhaka, Bangladesh \\ *Corresponding Author \\ Dr Farhat Jahan
}

\begin{abstract}
Objective: In this study our main goal is to evaluate the management and outcome of Peripheral ulcerative keratitis (PUK) in Bangladesh.

Method: This observational study was done in the in the National Institute of Ophthalmology \& Hospital from October 2018 to October 2019. A total of 100 consecutive patients were included. The diagnosis PUK was made on the basis of presence of crescent-shaped destructive inflammation within at least $2 \mathrm{~mm}$ of limbus associated with epithelial defect, stromal inflammatory cells and possibly stromal degradation.

Results: during the study, the mean random blood sugar was $11.4 \pm 5.4 \mathrm{mg} / \mathrm{dl}$ in and $9.1 \pm 4.1 \mathrm{mg} / \mathrm{dl} \mathrm{in}$ patients. $35 \%$ patients had blurred vision, followed by $25 \%$ had increased sensitivity to bright light, $40 \%$ had a sensation of a foreign object trapped in the eye. significant visual improvement was noted in severe cases $(p=0.001)$ and all those cases in which surgery was done after medical failure $(p=0.012)$. For severe diseases mean time to healing in the cases which were treated medically was $33.78 \pm 11.67$ days.

Conclusion: From our study we can conclude that, patients with PUK require thorough ocular and systemic investigations to detect the aetiology on which the treatment is based. Surgical intervention in perforated cases had good visual prognosis and anatomical success. In spite of complete resolution, continued, possibly lifelong, follow-up of cases is necessary since relapse may occur.

Keywords: Peripheral ulcerative keratitis (PUK), crescent-shaped destructive inflammation, ocular and systemic pattern.
\end{abstract}

\section{Introduction}

Peripheral ulcerative keratitis (PUK) is a potentially devastating disorder consisting of a crescent-shaped destructive inflammation at the margin of cornealstroma associated with an epithelial defect, presence of stromal inflammatory cells and progressive stromal degradation and thinning. ${ }^{1}$

It is a potentially devastating disorder which can present at any age. ${ }^{2}$ The unique anatomical and physiological characteristics of peripheral cornea explain its predilection for PUK. ${ }^{3}$ It may be the presenting manifestation of a potentially lethal 
systemic auto-immune vasculitic disease. Because of the varied etiologies of PUK, appropriate management requires the establishment of correct diagnosis. Dermatological, neurological, traumatic, infectious and post infectious disorders, abnormalities of the eyelids, systemic and local autoimmune diseases should be considered in the differential diagnosis of PUK. ${ }^{4-12}$ Antimicrobial therapy, systemic tetracycline, lid hygiene, correction of anatomical lid problems, punctal occlusion and temporary or permanent tarsorrhaphy may be required. ${ }^{4}$ However, in patients with an underlying collagen vascular disorder, systemic therapy with immunosuppressive and immunomodulator agents may decrease the likelihood of ocular morbidity.

In this study our main goal is to evaluate the management and outcome of Peripheral ulcerative keratitis (PUK) in Bangladesh.

\section{Objective}

\section{General Objective}

- To evaluate management and outcome of Peripheral ulcerative keratitis (PUK) in Bangladesh.

\section{Specific Objectives}

- To detect baseline investigations findings of patients.

- To identify symptoms of the peripheral Ulcerative Keratitis.

\section{Methodology}

\begin{tabular}{|l|l|}
\hline Type of study & Observational study. \\
\hline Place of study & $\begin{array}{l}\text { National Institute of } \\
\text { Ophthalmology \& Hospital }\end{array}$ \\
\hline Study period & October 2018 to October2019 \\
\hline $\begin{array}{l}\text { Study } \\
\text { population }\end{array}$ & $\begin{array}{l}100 \text { consecutive patients of PUK } \\
\text { who presented to the Cornea } \\
\text { Services. }\end{array}$ \\
\hline $\begin{array}{l}\text { Sampling } \\
\text { technique }\end{array}$ & Purposive \\
\hline
\end{tabular}

\section{Method}

The diagnosis PUK was made on the basis of presence of crescent-shaped destructive inflammation within at least $2 \mathrm{~mm}$ of limbus associated with epithelial defect, stromal inflammatory cells and possibly stromal degradation. Patient details such as age, sex, socioeconomic status was noted. A detailed history was taken regarding the duration and type of symptoms, systemic associations and treatment taken. A meticulous ocular examination was done which included record of best corrected visual acuity (BCVA) and detailed slit lamp examination during which the involved quadrant (nasal, temporal, superior and inferior), extent of epithelial defect, infiltration, thinning (in clock hours in greatest and smallest meridian) and depth of corneal involvement were noted.

\section{Statistical Analysis}

Data were processed and analyzed using computer-based software SPSS (Statistical Package for Social Sciences) for windows version 22. Unpaired t-test was used to compare quantitative variables. Variables were expressed as range and mean $\pm \mathrm{SD}$. $\mathrm{p}$ value $<0.05$ were taken significant. Students' t test, Pearson's correlation coefficient test, multivariate logistic regression analysis and Fisher's exact test as applicable.

\section{Results}

In table-1 shows age distribution of the patients where most of the patients $(35.7 \%)$ belong to age group 50-60 years. The following table is given below in detail:

Table-1: Age distribution of the patients

\begin{tabular}{|l|c|c|}
\hline Variable & Distribution & Percentage (\%) \\
\hline \multirow{3}{*}{ Age (Years) } & & \\
\cline { 2 - 3 } & $30-40$ & 10.2 \\
\cline { 2 - 3 } & $40-50$ & 31.8 \\
\cline { 2 - 3 } & $50-60$ & 35.7 \\
\cline { 2 - 3 } & $60-70$ & 28.9 \\
\cline { 2 - 3 } & & \\
\hline
\end{tabular}

In figure-1 shows gender distribution of the patients where most of the patients were male, $56 \%$. The following figure is given below in detail: 


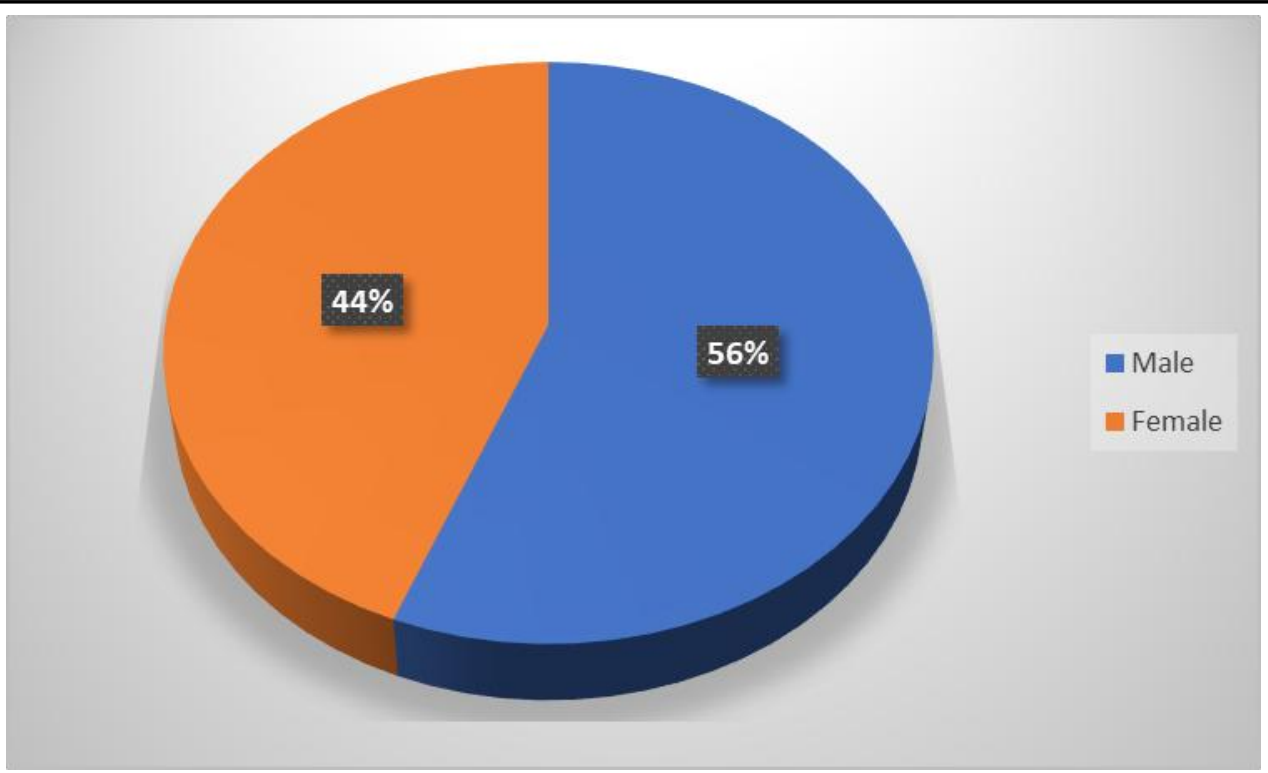

Figure-1: Gender distribution of the patients.

In figure -2 shows residential area distribution of the patients where $20 \%$ patients belong to urban area. The following figure is given below in detail:

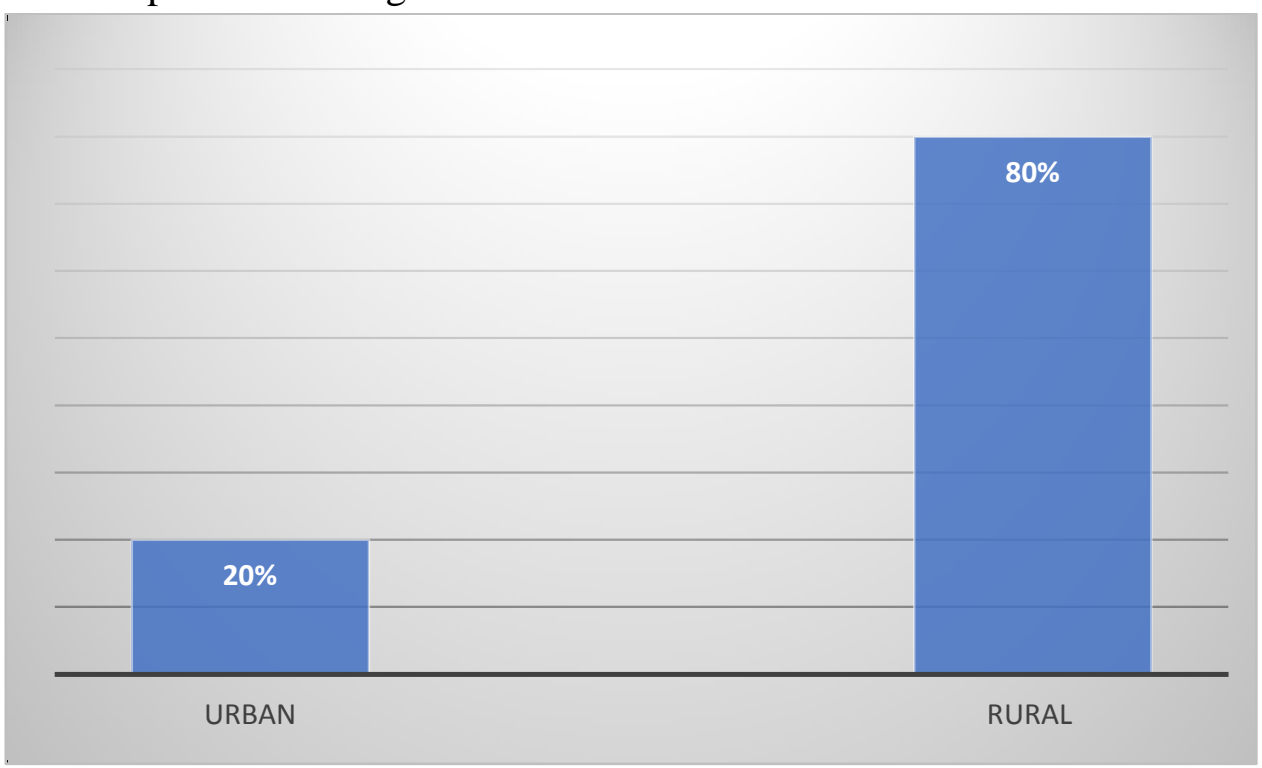

Figure -2: Residential area distribution of the patients

In table-2 shows economic status of patients where $60 \%$ were lower class. The following table is given below in detail:

Table-2: Economic status of patients

\begin{tabular}{|l|c|}
\hline Economic Status & \% \\
\hline Upper Class & $5 \%$ \\
\hline Middle class & $35 \%$ \\
\hline Lower class & $6 \%$ \\
\hline
\end{tabular}

In table-3 shows clinical characteristics of the patients where In table-1 shows baseline investigations findings of patients where the mean random blood sugar was $11.4 \pm 5.4 \mathrm{mg} / \mathrm{dl}$ in and
$9.1 \pm 4.1 \mathrm{mg} / \mathrm{dl}$ in patients. The following table is given below in detail:

Table-3: Baseline investigations findings of patients $(\mathrm{n}=100)$

\begin{tabular}{|l|c|}
\hline \multirow{2}{*}{ Baseline investigations } & $\begin{array}{c}\text { Group I } \\
(\mathbf{n = 1 0 0})\end{array}$ \\
\cline { 2 - 2 } & Mean \pm SD \\
\hline R B S. $(\mathrm{mmol} / \mathrm{L})$ & $11.4 \pm 5.4$ \\
\hline S. creatinine $(\mathrm{mg} / \mathrm{dl})$ & $1.0 \pm 0.2$ \\
\hline TC $(\mathrm{mg} / \mathrm{dl})$ & $209.0 \pm 48.6$ \\
\hline LDL-C $(\mathrm{mg} / \mathrm{dl})$ & $114.5 \pm 23.2$ \\
\hline
\end{tabular}


In figure-3 shows symptoms of the peripheral Ulcerative Keratitis where $35 \%$ patients had blurred vision, followed by $25 \%$ had increased sensitivity to bright light, $40 \%$ had a sensation of a foreign object trapped in the eye. The following figure is given below in detail:

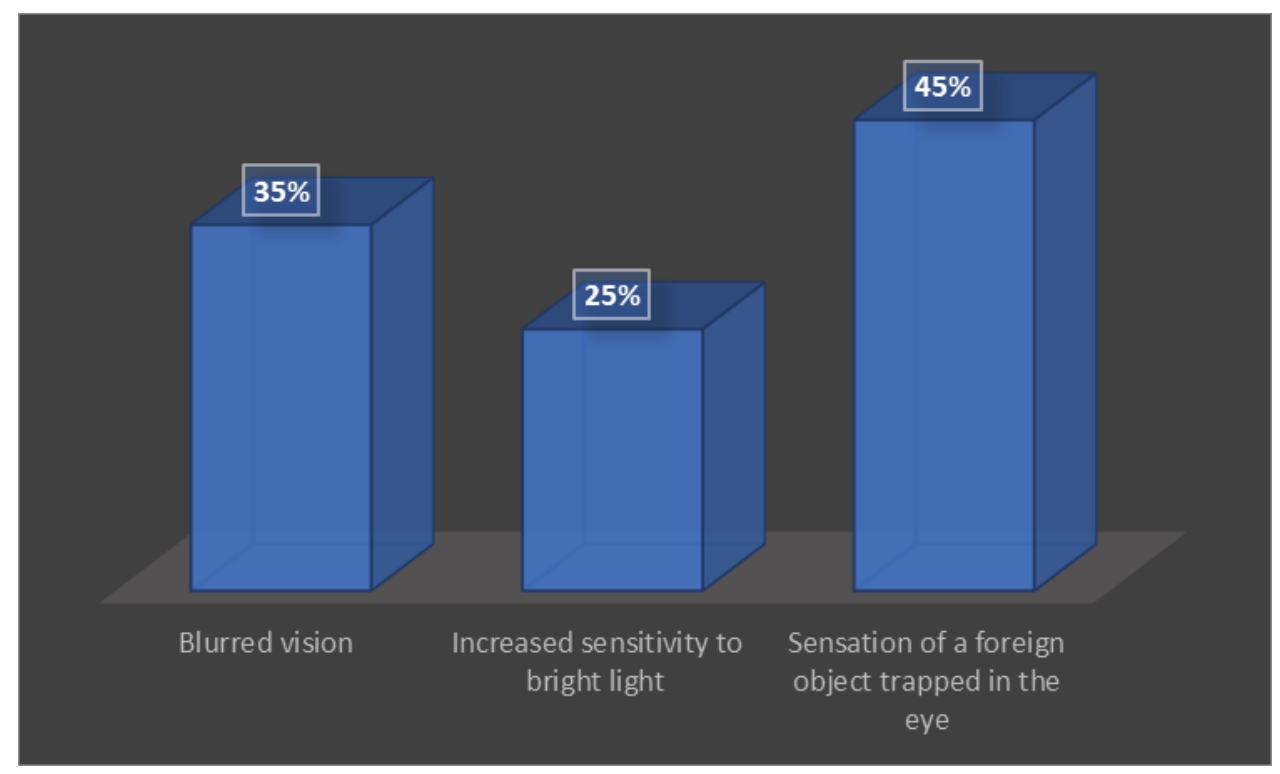

Figure-3: Symptoms of the peripheral Ulcerative Keratitis.

In figure-4 shows common etiology of disease where Mooren's ulcer present in $31.5 \%$ cases followed by microbiological infection $40 \%$ and systemic collagen vascular disease $28.5 \%$.The following figure is given below in detail:

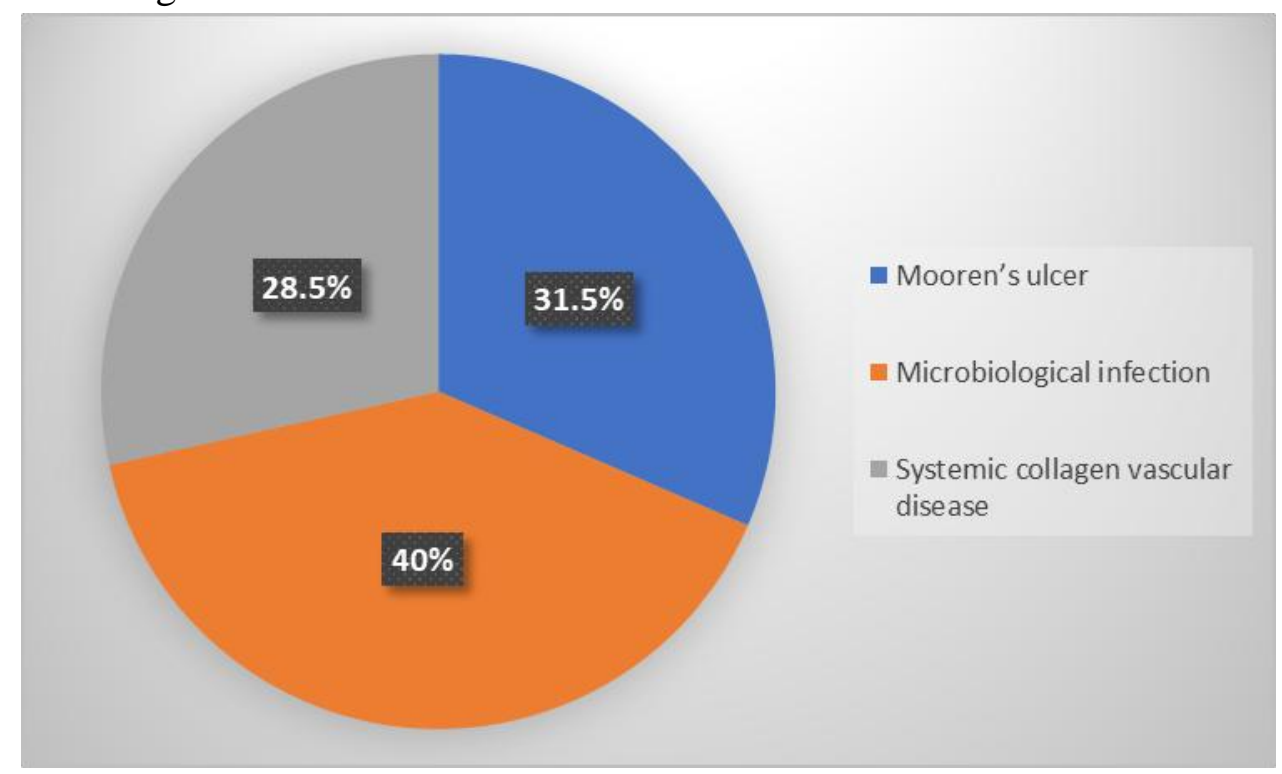

Figure-4: Common etiology of disease

In table-4 shows Visual acuity of patients presenting with PUK where $B C V A \geq 6 / 18$ was found in 14eyes with mild, 8 eyes with moderate and 1 eye with severe disease. BCVA $<3 / 60$ was seen in 3eyes with mild and moderate disease and 20 eyes with severe disease. The following table is given below in detail: 
Table-4: Visual acuity of patients presenting with PUK

\begin{tabular}{|l|c|c|c|}
\hline Visual acuity & $\begin{array}{c}\text { Before treatment } \\
\text { Group } \mathbf{- 1}(\mathbf{n}=\mathbf{5 0})\end{array}$ & $\begin{array}{c}\text { After treatment, } \\
\text { Group -1 (n= 50) }\end{array}$ & $\begin{array}{c}\text { Before } \\
\text { treatment, } \\
\text { Group-2 (n= 50) }\end{array}$ \\
\hline $\mathrm{BCVA} \geq 6 / 18$ & 14 & 8 & 1 \\
\hline $\mathrm{BCVA}<6 / 18$ to $\geq 6 / 60$ & 2 & 7 & 3 \\
\hline $\mathrm{BCVA}<6 / 60$ to $\geq 3 / 6$ & 1 & 6 & 12 \\
\hline $\mathrm{BCVA}<3 / 60$ & 3 & 3 & 20 \\
\hline
\end{tabular}

In table-5 shows management and outcome in patients with PUK where for severe diseases mean time to healing in the cases which were treated medically was $33.78 \pm 11.67$ days. The following table is given below in detail:

Table 5: Management and outcome in patients with PUK

\begin{tabular}{|l|c|c|c|}
\hline Outcome & Mild diseases & Moderate diseases & Severe diseases \\
\hline Mean duration of healing (days) & $7.87 \pm 2.13$ & $17.37 \pm 5.63$ & $33.78 \pm 11.67$ \\
\hline Medical treatment failure & $5 \%$ & $30 \%$ & $51 \%$ \\
\hline Primary surgical management & $0 \%$ & $0 \%$ & $49 \%$ \\
\hline Anatomical success & $90 \%$ & $85 \%$ & $80 \%$ \\
\hline Recurrence & $.1 \%$ & $5 \%$ & $9 \%$ \\
\hline Visual outcome & & & \\
Mean pretreatment BCVA: & $0.46 \pm 0.12$ & $0.25 \pm 0.05$ & $0.03 \pm 0.005$ \\
Mean post-treatment BCVA: & $0.52 \pm 0.20$ & $0.29 \pm 0.11$ & $0.11 \pm 0.04$ \\
\hline
\end{tabular}

In table-6 shows comparison of visual outcome in medically versus surgically managed cases where significant visual improvement was noted in severe cases $(p=0.001)$ and all those cases in which surgery was done after medical failure $(p=0.012)$. The following table is given below in detail:

Table-6: Comparison of visual outcome in medically versus surgically managed cases

\begin{tabular}{|l|c|c|c|}
\hline Visual acuity & $\begin{array}{c}\text { Mean pretreatment } \\
\text { BCVA }\end{array}$ & $\begin{array}{c}\text { Mean post- } \\
\text { treatment BCVA }\end{array}$ & p Value \\
\hline Primary surgical furgical & $0.02 \pm 0.01$ & $0.13 \pm 0.04$ & 0.001 \\
\hline $\begin{array}{l}\text { Medical followed by } \\
\text { treatment }\end{array}$ & $0.11 \pm 0.07$ & $0.20 \pm 0.09$ & 0.0012 \\
\hline $\begin{array}{l}\text { Only medically treated cases } \\
\text { insevere+moderate cases }\end{array}$ & $0.18 \pm 0.10$ & $0.20 \pm 0.06$ & 0.364 \\
\hline
\end{tabular}

\section{Discussion}

The demographic data of our study resembled previously reported studies for patients with PUK in that most patients were 50-60 years. ${ }^{5}$ PUK was more common in men $(56 \%)$ and was similar to the results of the study carried out by one article. ${ }^{7}$ They also found that, most of the patients were from rural back-ground (66\%) and were from low socioeconomic groups $(73 \%) .{ }^{8}$ In our study we found that, $60 \%$ were lower class and $80 \%$ were from rural.

In one study they reported that, of the 65 patients in our study, 24(31.5\%) were tobacco smokers. ${ }^{9}$ In our series, there was less number of bilateral cases. $^{9}$

Most patients (69\%) presented to us rather late that is, after 15 days and had severe disease. The mean delay between appearance of symptoms and presentation to hospital was directly related to severity of disease. significant visual improvement was noted in severe cases $(p=0.001)$ and all those cases in which surgery was done after medical failure $(\mathrm{p}=0.012)$. Which is quite similar to other study. ${ }^{9}$ Number of patients who were on topical corticosteroids along with antibiotics, topical steroids could have suppressed 
the inflammation so that the patients might have been less symptomatic and thus may have been having irregular follow-up with their treating ophthalmologists. ${ }^{10}$

\section{Conclusion}

From our study we can conclude that, patients with PUK require thorough ocular and systemic investigations to detect the aetiology on which the treatment is based. Surgical intervention in perforated cases had good visual prognosis and anatomical success. In spite of complete resolution, continued, possibly lifelong, follow-up of cases is necessary since relapse may occur.

\section{References}

1. Robin JB, Schanzlin DJ, Verity SM,et al. Peripheral corneal disorders. Surv Ophthalmol 1986;31:1-36.

2. Mondino BJ. Inflammatory diseases of the peripheral cornea. Ophthalmology 1988; 95:463-72.

3. Dana M, Qian Y, Hamrah P. Twenty-fiveyear panorama of corneal immunology: emerging concepts in the immunopathogenesis of microbial keratitis, peripheral ulcerative keratitis, and corneal transplant rejection. Cornea 2000;19:625-43.

4. Messmer EM, Foster CS. Vasculitic peripheral ulcerative keratitis. Surv ophthalmol 1999;43:379.

5. McKibbin M, Isaacs JD, Morrell AJ. Incidence of corneal melting in association with systemic disease in the Yorkshire Region, 1995-7.Br J Ophthalmol 1999;83: 941-3.

6. Sainz de la Maza M, Foster CS, Jabbur NS, et al. Ocular characteristics and disease associations in scleritis-associated peripheral keratopathy. Arch Ophthalmol 2002;120:15-19.

7. Srinivasan M, Zegans ME, Zelefsky JR, et al. Clinical characteristics of Mooren's ulcer in South India.Br J Ophthalmol 2007;91:570-5.

8. Foster CS, Forstot SL, Wilson LA. Mortality rate in rheumatod arthritis patients developing necrotizing scleritis or PUK.Ophthalmology1984;91:1253.

9. Watson PG, Hayreh SS. Scleritis and episcleritis.Br J Ophthalmol1976;60:163.

10. Ladas JG, Mondino BJ. Systemic disorders associated with peripheral corneal ulceration. Curr Opin Ophthalmol 2000;11:468-71. 